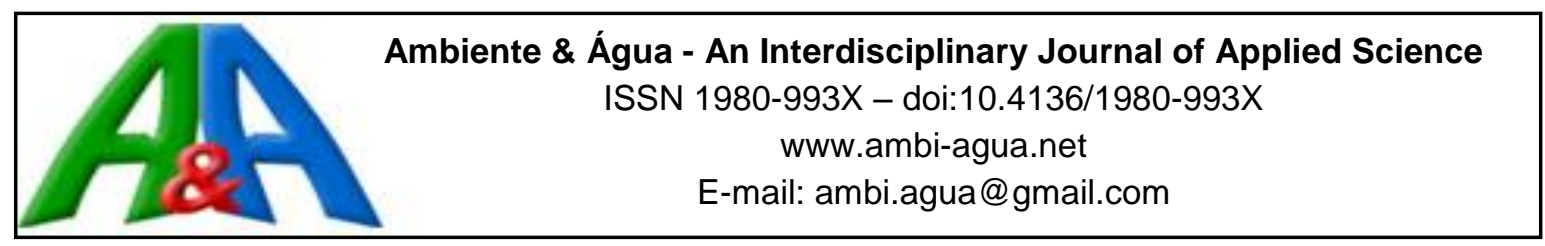

\title{
Evaluation of methods for estimating atmospheric emissivity in Mato-Grossense Cerrado
}

\author{
ARTICLES doi:10.4136/ambi-agua.2288
}

Received: 05 Jun. 2018; Accepted: 06 Feb. 2019

\section{Jonh Billy Silva ${ }^{1,2}$; Denilton Carlos Gaio ${ }^{1,2}{ }^{(D}$; \\ Leone Francisco Amorim Curado ${ }^{1,2}$; José de Souza Nogueira ${ }^{1,2}$; Luiz Claudio Galvão Valle Júnior ${ }^{3}$ (D); Thiago Rangel Rodrigues ${ }^{4 *(i D)}$}

\author{
${ }^{1}$ Universidade Federal de Mato Grosso (UFMT), Cuiabá, MT, Brasil \\ Programa de Pós-Graduação em Física Ambiental (PPGFA). E-mail: jonhbilly9@gmail.com, \\ dcgaio@fisica.ufmt.br, leonecurado@gmail.com,nogueira@ufmt.br \\ ${ }^{2}$ Universidade Federal de Mato Grosso (UFMT), Coxipó, MT, Brasil \\ Instituto de Física. E-mail: jonhbilly9@gmail.com, dcgaio@fisica.ufmt.br, \\ leonecurado@gmail.com,nogueira@ufmt.br \\ ${ }^{3}$ Universidade Federal do Mato Grosso do Sul (UFMS), Campo Grande, MT, Brasil \\ Programa de Pós-Graduação em Tecnologias Ambientais (PGTA). E-mail: luizvallejr@gmail.com \\ ${ }^{4}$ Universidade Federal de Mato Grosso do Sul (UFMS), Campo Grande, MT, Brasil \\ Laboratório de Ciências Atmosféricas (LCA). E-mail: thiago.r.rodrigues@ufms.br \\ *Corresponding author
}

\begin{abstract}
This study analyzed the performance of the Brunt (1932), Swinbank, (1963), Idso and Jackson (1969), Brutsaert (1975), Idso (1981), and Bignami et al. (1995) methods to estimate atmospheric emissivity under grass-dominated savannas (known as campo sujo Cerrado), in the region of Baixada Cuiabana. The estimates were compared with data obtained by energy balance equation in two seasons, dry season (May to August), and wet season (September to December) of 2009. The Swinbank and Idso and Jackson methods, that consider only air temperature, show better performances for the wet season. However, methods that consider water vapor pressure and air temperature (Brunt, Brutsaert, Bignami and Idso) show good performances for the dry season. The Idso and Brutsaert methods show the highest index of agreement and are recommended to estimate atmospheric emissivity for the region.
\end{abstract}

Keywords: air temperature, campo sujo Cerrado, water vapor pressure.

\section{Avaliação de métodos para estimativa da emissividade atmosférica no cerrado Mato-Grossense}

\section{RESUMO}

Este trabalho analisou o desempenho dos métodos de Brunt (1932), Swinbank (1963), Idso and Jackson (1969), Brutsaert (1975), Idso (1981) e Bignami et al. (1995) para estimativa da emissividade atmosférica para dados obtidos na região do Cerrado Campo Sujo, na baixada cuiabana. As estimativas foram comparadas com dados calculados pela equação do balanço de energia para dois períodos estudados, seco (maio a agosto) e chuvoso/úmido (setembro a dezembro) de 2009. Os métodos de Swinbank e Idso and Jackson, que levam em consideração 
apenas a Temperara do ar, obtiveram melhor desempenho durante o período chuvoso. Em contrapartida, os métodos que levam em consideração a pressão de vapor d'água e a temperatura do ar (Brunt, Brutsaert, Bignami e Idso) tiveram melhor desempenho durante a estação seca, sendo as equações de Idso e Brutsaert que apresentaram melhor desempenho para o local e período estudados, obtendo os maiores índices de concordância, e sendo assim, as equações mais indicadas para a estimativa da emissividade atmosférica para o local de estudo.

Palavras-chave: campo sujo Cerrado, pressão de vapor d'água, temperatura do ar.

\section{INTRODUCTION}

Tropical savannas cover approximately $12 \%$ of the Earth's land area (Scholes and Archer, 1997) and are characterized by high plant species diversity (Giambelluca et al., 2009). The Brazilian savanna (locally known as Cerrado) covers about $24 \%$ of the territory and is the dominant vegetation in areas subjected to a prolonged dry season (San José et al., 1998). In the last decades, the anthropic activities in the Cerrado have been causing strong changes in this biome, in particular, in its conversion to pastures and the production of soybean and sugarcane (Klink and Moreira, 2002; Rodrigues et al., 2014), besides the high rates of deforestation that are causing a mosaic of natural forests and arable land (Biudes et al., 2015). That mosaic implies land cover changes, provoking changes in the distribution of solar energy that is available to the environment (Novais et al., 2015; Faria et al., 2018), which affects directly the biophysical process linked to regional energy balance (Rodrigues et al., 2016).

One way to observe changes caused by anthropogenic action is by characterizing variations in surface radiation balance values, because the fluctuation of these values results in energy partitioning. For example, outgoing longwave radiation (OLR) is very important for meteorological studies, such as predicting diurnal temperature variations, frosts, and nighttime fog, as well as evaluations of radiation cooling of buildings at night (Jimenez et al., 1987). However, it is the hardest variable of radiation balance components to measure (Aguiar et al., 2011).

Since atmospheric emissivity $(\varepsilon)$ is a determining factor for longwave radiation (OLR), many studies have been committed to analyze atmospheric behavior. Considering that atmospheric gases absorb and emit radiation, atmospheric emissivity $(\varepsilon)$ can be presented as a function, the variation of which depends on water vapor content in the atmosphere and air temperature (Heitor et al., 1991), as water vapor acts as a thermoregulator by absorbing infrared radiation.

According to the Stefan-Boltzmann Law (Equation 1), every body emits radiant energy, which depends on its temperature and emissivities, and the latter is calculated by a ratio of the energy radiated by the body to the energy radiated by a black body for the same wavelength. Any object that is not a real black body has an emissivity value under 1 and higher than 0 (Equation 1).

$R=\sigma \varepsilon T^{4}$

Where $\sigma=5.6697 \times 10^{-8} \mathrm{~W} \mathrm{~m}^{-2} \mathrm{~K}^{-4}$ is the Stefan-Boltzmann Constant, $T(\mathrm{~K})$ is the air temperature, $\varepsilon$ is the emissivity, and $\mathrm{R}$ is the radiant energy.

Then, $\mathrm{R}$ can be considered as longwave radiation under clear sky conditions, being modelled as a function of air temperature (Tar), or actual water vapor pressure (ea), or both. Therefore, any method used to estimated of ORL can be rewritten using the Stefan-Boltzmann Law and estimates atmospheric emissivity $(\varepsilon)$. 
The majority of equations that estimate atmospheric emissivity using longwave radiation are only valid for clear sky days, and show better results when a daily basis or a long-term average is considered (Von Randow and Alvalá, 2006).

Curado et al. (2011), studying the Pantanal Mato Grossense, obtained higher atmospheric emissivity values during the wet season, because during this period there were a higher content of water in the atmosphere and quantity of clouds compared to the dry season. Following the same line of research, Nogueira and Lima (2011) assured that the higher radiation absorption by the clouds cause the rise of air temperature, and consequently raises its emission; i.e., the bodies that absorb more radiation also are the ones that emit more radiation (black body radiation law)

Considering how important is effect of campo sujo Cerrado on the climate of Mato Grosso state and the lack of information about atmospheric emissivity for this biome, the objective of this study was to assess the performance of the Brunt (1932), Swinbank (1963), Idso and Jackson (1969), Brutsaert (1975), Idso (1981), and Bignami et al. (1995) models on atmospheric emissivity ( $\varepsilon$ ) estimates for campo sujo Cerrado from May to December 2009, compared with emissivity values obtained by the energy balance equation.

\section{MATERIALS AND METHODS}

\subsection{Study Area}

The study was conducted at the Fazenda Miranda (FM) in the region of Baixada Cuiabana, located $15 \mathrm{~km}$ away from Cuiaba, Mato Grosso, Brazil (1543'53" S; 5604'18" W; $157 \mathrm{~m}$ ). The study site was a mixed forest-grassland (locally known as campo sujo or "dirty field") that was partially deforested approximately 35 years ago (Rodrigues et al., 2014).

Vegetation consists predominantly of grasses and tree species C. americana and Diospyros hispida A. DC. According to the Köppen climate classification system, the climate in this area is Aw, tropical semi-humid, with dry winters and wet summers (Rodrigues et al., 2016). Mean annual rainfall and temperature are $1420 \mathrm{~mm}$ and $26.5^{\circ} \mathrm{C}$, respectively, and rainfall is seasonal (Vourlitis and Da Rocha, 2011). The range of mean monthly air temperature is wider than tropical and subtropical moist forests, with a minimum of $23.5^{\circ} \mathrm{C}$ in June and a maximum of $28.6^{\circ} \mathrm{C}$ in September (Vourlitis and Da Rocha, 2011). The research area is on a flat terrain at an elevation of $157 \mathrm{~m}$ above sea level. The soil type is a rocky, dystrophic red-yellow latosol locally known as Solo Concrecionário Distrófico (CPRM, 1982).

\subsection{Instrumentation}

Micrometeorological measurements were conducted between May to December 2009, where two local defined seasons can be observed: the dry season, with rainfall below $100 \mathrm{~mm}$ (May to August); and the wet season, with rainfall above $100 \mathrm{~mm}$ (September to December). A micrometeorological tower enabled the collection of data on air temperature (Tar), relative humidity $(\mathrm{RH})$, wind speed $(\mathrm{u})$, precipitation $(\mathrm{Ppt})$, soil temperature $(\mathrm{Ts})$, soil heat flux $(\mathrm{G})$, net radiation $(\mathrm{Rn})$ and solar radiation $(\mathrm{Rs})$.

Tar and RH were measured $10 \mathrm{~m}$ above the ground level using a thermohygrometer (HMP45AC, Vaisala Inc., Woburn, MA, USA). Wind speed was measured $10 \mathrm{~m}$ above the ground level using anemometer (03101 R.M. Young Company), and G was measured using heat flux plates (HFP01-L20, Hukseflux Thermal Sensors BV, Delft, Netherlands) installed $1.0 \mathrm{~cm}$ below the soil surface, with one placed in a sandy soil type and the other placed in a laterite soil type, which were typical of the local soil in the tower footprint. Rn and Rs were measured $5 \mathrm{~m}$ above ground using a net radiometer (NR-LITE-L25, Kipp and Zonen, Delft, Netherlands) and a pyranometer (LI200X, LI-COR Biosciences, Inc., Lincoln, NE, USA), respectively. Precipitation was measured using a tipping bucket rainfall gauge (TR-525M, Texas Electronics, Inc., Dallas, TX, USA). The sensors were connected to a data logger 
(CR1000, Campbell Scientific, Inc., Logan, UT, USA) that scanned each sensor every $30 \mathrm{~s}$ and stored average, and in the case of Ppt, total quantities every $30 \mathrm{~min}$.

\subsection{Atmospheric Emissivity Calculation}

According to Duarte et al. (2006), since atmosphere does not have constant temperature, a local parametrization of atmospheric emissivity $(\varepsilon)$ is necessary, which depends on air temperature.

We tested six different models that can be used in the local temperature range (Table 1). The first two models to estimate emissivity ( $\varepsilon$ ) were proposed by Swinbank (1963), and Idso and Jackson (1969). Both models were chosen because they only consider temperature in their estimates, in a range of 2 to $29^{\circ} \mathrm{C}$ and -29 to $37^{\circ} \mathrm{C}$, respectively. Table 1 also shows the models proposed by Brutsaert (1975), Brunt (1932), Bignami (1995) and Idso (1981), that were chosen because they work in a temperature range between -40 and $45^{\circ} \mathrm{C}$ and consider actual water vapor pressure (ea) in hPa (Equation 2) (Idso, 1981; Prata, 1996; Duarte et al., 2006).

Table 1. Equations used to estimate atmospheric emissivity $(\varepsilon)$, where $\sigma$ is the Stefan-Boltzmann constant $\left(5.6697 \times 10^{-8} \mathrm{~W} \mathrm{~m}^{-2} \mathrm{~K}^{-4}\right), e_{a}$ is the actual water vapor pressure $(\mathrm{hPa})$, and Tar is the air temperature $(\mathrm{K})$ next to the surface.

\begin{tabular}{ll}
\hline Model & Equation \\
\hline Brunt (1932) & $\varepsilon=0,52+0,065 \sqrt{e_{a}}$ \\
Swinbank (1963) & $\varepsilon=9,2 \cdot 10^{-6} T_{a r}{ }^{2}$ \\
Idso and Jackson (1969) & $\varepsilon=1-0,26 \exp \left[-7,77 \cdot 10^{-4}\left(273-T_{a r}\right)\right]$ \\
Brutsaert (1975) & $\varepsilon=1,24\left(e_{a} / T_{a r}\right)^{1 / 7}$ \\
Idso (1981) & $\varepsilon=0,7+5,95.10^{-5} e_{a} \exp \left(1500 / T_{a r}\right)$ \\
Bignami (1995) & $\varepsilon=0,684+0,0056 e_{a}$ \\
\hline
\end{tabular}

Actual water vapor pressure $(e a)$ is described as Equation 2.

$e_{a}=\frac{e_{s} \cdot R H}{100}$

Where $e_{s}$ is the saturation water vapor pressure determined by the Tetens Equation (Tetens, 1930) (Equation 3).

$e_{S}=6,1078 \cdot 10^{\frac{7,5 \cdot T a r}{273,3+T_{a r}}}$

It is important to highlight that the methods used in this study were originally created to estimate ORL and by Equation 1 we could estimate $\varepsilon$.

The emissivity over fully vegetated surface show low variability, with its value usually ranging between 0.94 to 0.98 according to Food And Agriculture Organization Of The United Nations (1991). Nevertheless, the most-used value for surface emissivity is 1.

The atmospheric emissivity values estimated by the six methods presented in Table 1 were compared with emissivity values calculated by the energy balance equation (Equation 4). Its input data were measured during the study period by the instrumentation cited in Section 2.2.

$\varepsilon=\frac{R n-R g+r R g+\sigma T s^{4}}{\sigma T a r^{4}}$

Where $\mathrm{Rn}\left(\mathrm{Wm}^{-2}\right)$ is the net radiation, $\mathrm{Rg}\left(\mathrm{Wm}^{-2}\right)$ is the incident global radiation, $\mathrm{rRg}$ $\left(\mathrm{Wm}^{-2}\right)$ is the surface albedo, $\sigma \operatorname{Tar}^{4}\left(\mathrm{~K}^{4}\right)$ is the energy emitted by the atmosphere, $\sigma \operatorname{Ts}^{4}\left(\mathrm{~K}^{4}\right)$ is the energy emitted by the soil, and $\varepsilon$ is the atmospheric emissivity. 
All the equations analyzed in this study make the assumption that $\varepsilon$ is a function of temperature and/or vapor pressure near the ground.

\subsection{Statistical analysis}

The performance in atmospheric emissivity for each equation was assessed statistically using Mean Absolute Deviation (MAD), Mean Squared Error (MSE), and coefficient of determination $\left(\mathrm{R}^{2}\right)$ by linear regression without interception. Also were used Willmott's index of agreement (d), which indicates the estimation agreement level when compared with measured values (Willmott et al., 1985), the Pearson correlation coefficient (r), which indicates the correlation level between observed and estimated values, and the confidence coefficient or Camargo and Sentelhas performance (c). The value of $d$ and $r$ must varies from 0 to 1 , indicating non-concordance and perfect concordance, respectively (Machado et al., 2015).

\section{RESULTS AND DISCUSSION}

\subsection{Air temperature and relative humidity seasonal variation analysis}

Sky conditions are directly related to atmospheric emissivity; therefore, a study of air temperature (Tar) and relative humidity (RH) seasonal variation is needed, since atmospheric conditions, as well as its components, mainly water vapor, have a strong influence on longwave radiation quantity that is irradiated to Earth's surface.

Mean monthly air temperature for the dry season varied from 11.22 to $31.95^{\circ} \mathrm{C}$, with an average of $26.03^{\circ} \mathrm{C}$. For the wet season, air temperature values ranged from 17.58 to $34.22^{\circ} \mathrm{C}$, with an average of $28.33^{\circ} \mathrm{C}$ (Figure 1).

Relative humidity varied between $31.56 \%$ and $94.31 \%$ for the dry season and $35.21 \%$ and $94.75 \%$ for wet season, with average values of $60.59 \%$ and $64.99 \%$, respectively. It was not possible to observe a pattern during the year, considering that its value in dry season decreases in comparison with wet season. This relation can be observed due to rainfall regularity, from September to March, and absence, from May to August.

Thus, it is expected for atmospheric emissivity values to be higher in the wet season than in the dry season, since higher values of relative humidity and air temperature can be observed during the wet season.

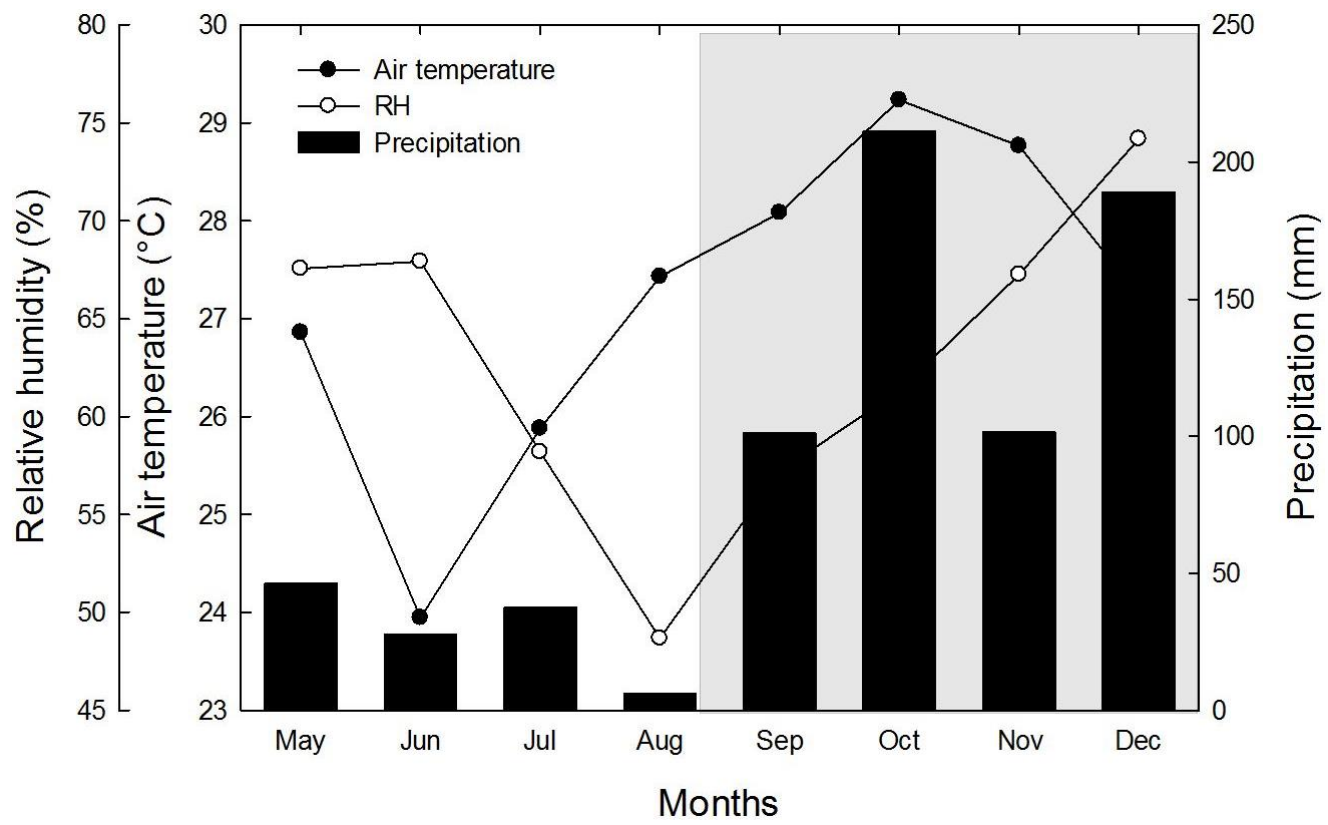

Figure 1. Mean monthly air temperature, relative humidity, and accumulated rainfall in 2009. The shaded area represents wet season, i.e., when rainfall $>100 \mathrm{~mm}$. 
Accumulated rainfall average value was equal to $29.38 \mathrm{~mm}$ for the dry season and $149.08 \mathrm{~mm}$ for the wet season. The lowest value was observed in August, $6.20 \mathrm{~mm}$, while the highest was observed in October, $211 \mathrm{~mm}$.

\subsection{Atmospheric emissivity behavior analysis}

The method used as reference in this study, the energy balance equation, has small instrumental errors inherent to micrometeorological data collection. Therefore, due to intrinsic errors related to the method, we found atmospheric emissivity values above 1.00, which is theoretically a black body emissivity. Table 2 shows the Mean Absolute Deviation (MAD) and Mean Squared Error (MSE) values.

Table 2. Minimum (Min), average (Avg), and maximum (Max) values of monthly atmospheric emissivity computed by energy balance (BE), Brutsaert (BT), Bignami (BG), Brunt (BR), Idso (ID), Idso and Jackson (IJ), and Swinbank (SW) equations under campo sujo Cerrado at the Fazenda Miranda.

\begin{tabular}{lcccccccccccccc}
\hline \multicolumn{10}{c}{ Dry season } \\
\hline & \multicolumn{1}{c}{ May } & \multicolumn{1}{c}{ June } & \multicolumn{1}{c}{ July } & \multicolumn{3}{c}{ August } \\
\hline & Min & Avg & Max & Min & Avg & Max & Min & Avg & Max & Min & Avg & Max \\
\hline BE & 0.93 & 0.98 & 1.06 & 0.88 & 0.95 & 1.05 & 0.88 & 0.94 & 1.00 & 0.86 & 0.93 & 1.08 \\
IJ & 0.79 & 0.85 & 0.87 & 0.80 & 0.84 & 0.86 & 0.76 & 0.84 & 0.87 & 0.74 & 0.83 & 0.89 \\
SW & 0.77 & 0.82 & 0.84 & 0.78 & 0.82 & 0.84 & 0.74 & 0.82 & 0.84 & 0.69 & 0.80 & 0.86 \\
BT & 0.84 & 0.88 & 0.91 & 0.82 & 0.87 & 0.91 & 0.82 & 0.86 & 0.91 & 0.80 & 0.83 & 0.89 \\
BR & 0.80 & 0.90 & 0.94 & 0.82 & 0.89 & 0.93 & 0.76 & 0.90 & 0.94 & 0.81 & 0.92 & 0.98 \\
BG & 0.77 & 0.83 & 0.85 & 0.78 & 0.82 & 0.85 & 0.76 & 0.81 & 0.84 & 0.77 & 0.80 & 0.84 \\
ID & 0.83 & 0.90 & 0.94 & 0.84 & 0.89 & 0.94 & 0.84 & 0.87 & 0.92 & 0.82 & 0.85 & 0.93 \\
\hline
\end{tabular}

\section{Wet Season}

\begin{tabular}{lllllllllllllll}
\hline & \multicolumn{3}{c}{ September } & \multicolumn{3}{c}{ October } & \multicolumn{3}{c}{ November } & \multicolumn{3}{c}{ December } \\
\hline & Min & Avg & Max & Min & Avg & Max & Min & Avg & Max & Min & Avg & Max \\
\hline BE & 0.89 & 1.03 & 1.11 & 0.97 & 1.04 & 1.09 & 0.92 & 1.04 & 1.12 & 0.85 & 1.03 & 1.09 \\
IJ & 0.80 & 0.86 & 0.90 & 0.85 & 0.87 & 0.89 & 0.83 & 0.86 & 0.88 & 0.83 & 0.87 & 1.00 \\
SW & 0.82 & 0.83 & 0.87 & 0.84 & 0.84 & 0.86 & 0.87 & 0.84 & 0.85 & 0.88 & 0.71 & 0.84 \\
BT & 0.81 & 0.86 & 0.90 & 0.90 & 0.87 & 0.89 & 0.86 & 0.88 & 0.91 & 0.69 & 0.76 & 0.91 \\
BR & 0.78 & 0.92 & 1.00 & 0.83 & 0.93 & 0.98 & 0.84 & 0.93 & 0.96 & 0.68 & 0.88 & 0.94 \\
BG & 0.78 & 0.82 & 0.85 & 0.82 & 0.85 & 0.87 & 0.82 & 0.86 & 0.87 & 0.82 & 0.83 & 0.87 \\
ID & 0.84 & 0.88 & 0.90 & 0.88 & 0.91 & 0.89 & 0.91 & 0.93 & 0.88 & 0.92 & 0.80 & 1.00 \\
\hline
\end{tabular}

The energy balance method was adopted due to lack of local values of atmospheric emissivity in literature that could be considered as reference values, specifically for campo sujo Cerrado. Regarding the other six models, they have small instrumental errors too; they also show small errors related to each method, since the models have local parameters from where the model was initially proposed (constant values presented in each equation). Those parameters were not modified to the study area, as we wanted to evaluate the performance of each method in their original proposes.

Therefore, the results show that the six models have errors close to the instrumental errors used in this study, which makes this model an alternative to estimate atmospheric emissivity in the campo sujo Cerrado, using only two variables: air temperature (Tar) and relative humidity (RH). 
These unique parameters (local constants) are extremely important to evaluate which method is more appropriate for campo sujo Cerrado. The Swinbank, and Idso and Jackson equations consider air temperature only, while the Brunt, Brutsaert, Idso, and Bignami equations consider, besides $T$, relative humidity, which is an effect of water vapor volume in the atmosphere. It is expected of those models that consider $T$ only to estimate better values of atmospheric emissivity during dry seasons, considering the mean precipitation to be close to 0 . For the other models, it is likely that they estimate better values of $\varepsilon$ during wet seasons, because water volume in atmosphere increases significantly, raising RH values.

During the study period, the mean daily atmospheric emissivity $(\varepsilon)$ calculated by the energy balance equation showed large variation during the dry season, ranging from 0.88 to 1.00 , which is the maximum value. For Brutsaert and Brunt methods, emissivity values during the dry season varied from 0.80 to 0.91 , and from 0.76 to 0.98 , respectively, showing that those models estimate atmospheric emissivity within range of energy balance (Figure 2). That also happened during the wet season (Figure 3). The emissivity values by energy balance equation ranged from 0.85 to values higher than 1.00. Using the Bignami and Idso models, the values varied from 0.78 to 0.87 , and 0.84 to 1.00 , respectively. The average, minimum and maximum monthly values of atmospheric emissivity are shown in Table 2.

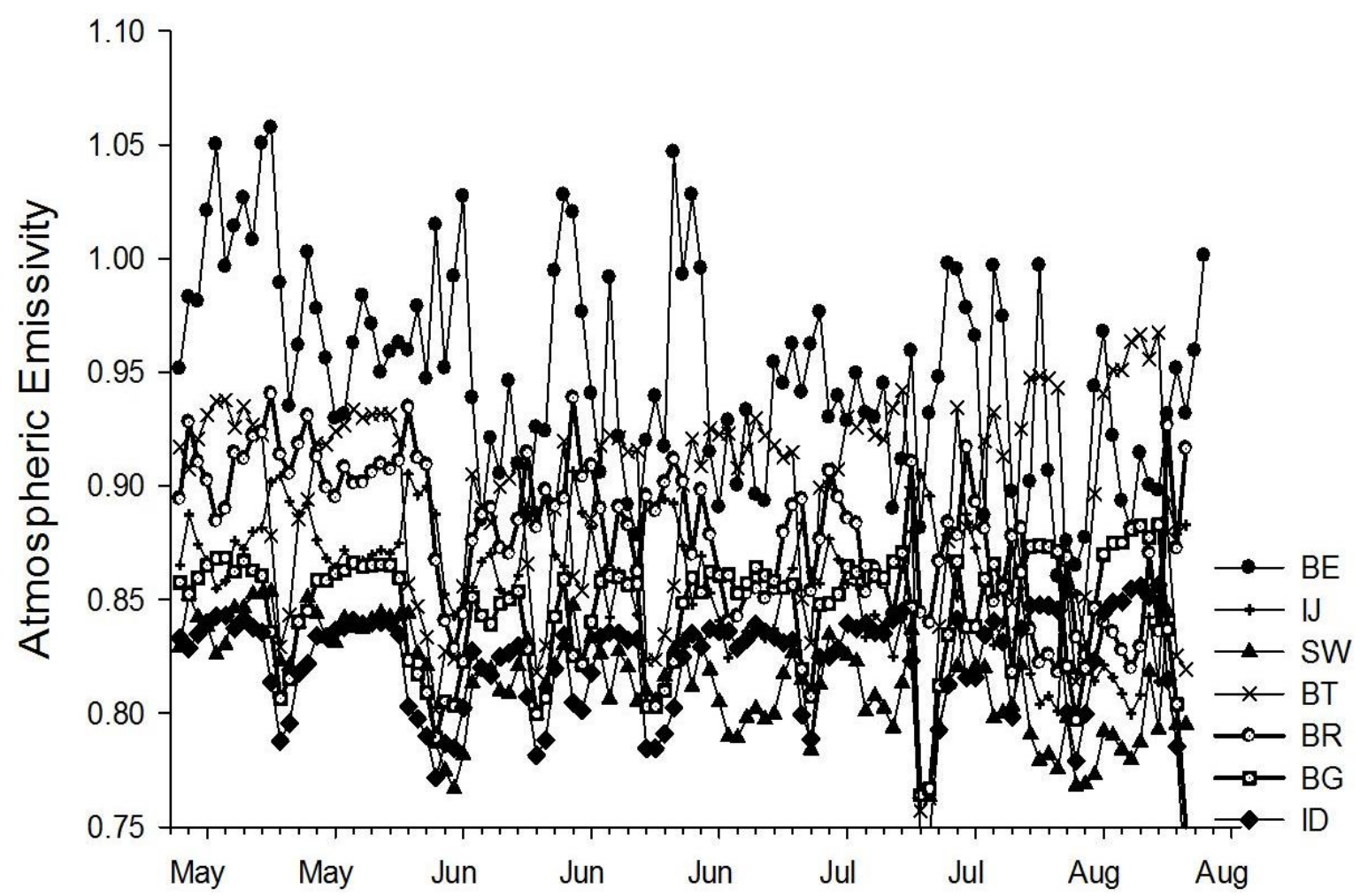

Figure 2. Mean daily atmospheric emissivity for the dry season computed by energy balance (BE), Brutsaert (BT), Bignami (BG), Brunt (BR), Idso (ID), Idso and Jackson (IJ), and Swinbank (SW) equations under campo sujo Cerrado at the Fazenda Miranda. 


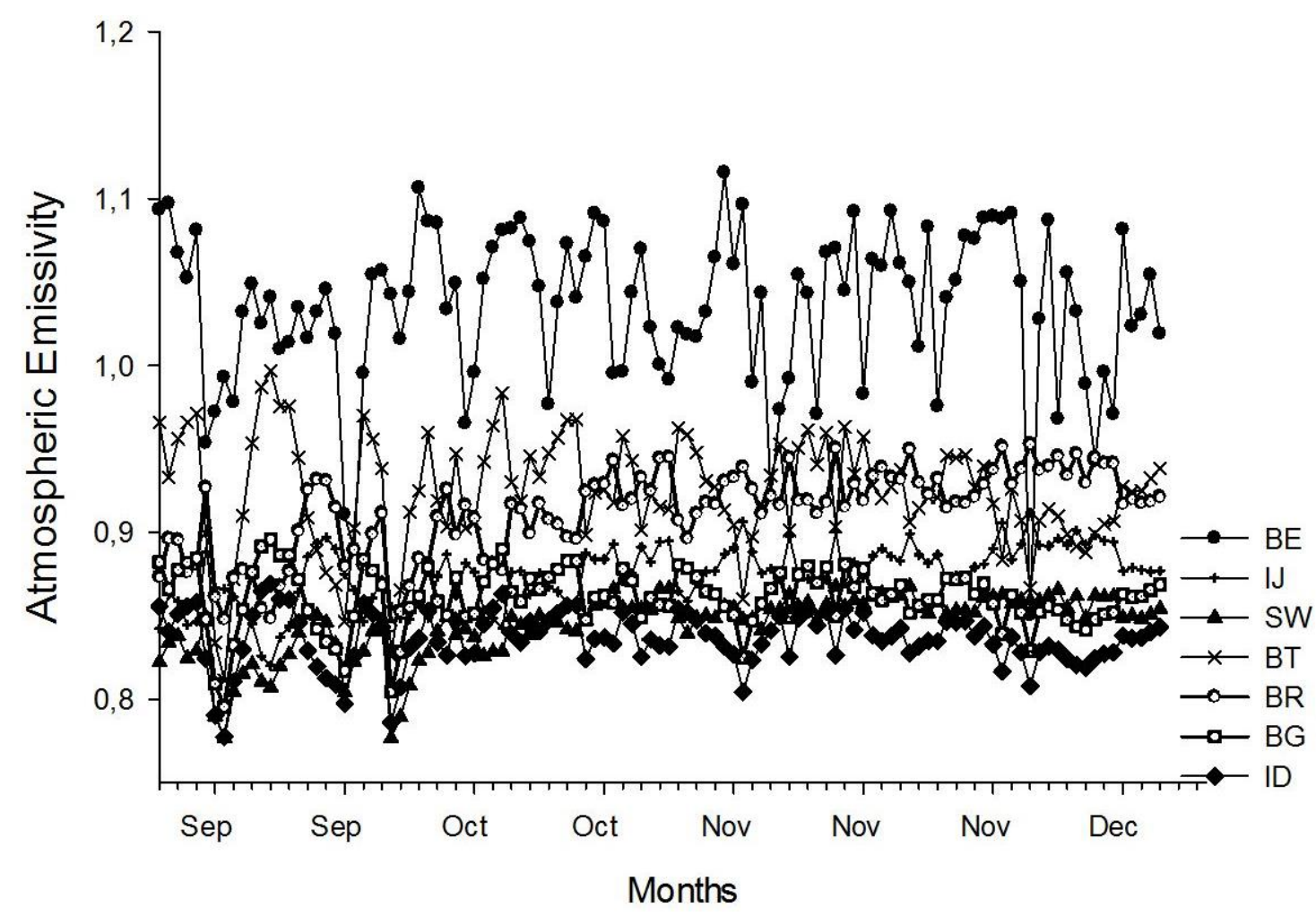

Figure 3. Mean daily atmospheric emissivity for the wet season computed by energy balance (BE), Brutsaert (BT), Bignami (BG), Brunt (BR), Idso (ID), Idso and Jackson (IJ), and Swinbank (SW) equations under campo sujo Cerrado at the Fazenda Miranda.

\subsection{Atmospheric emissivity models performance}

To evaluate the performance of the equations proposed by Brunt, Swinbank, Idso and Jackson, Brutsaert, Idso, and Bignami to estimate atmospheric emissivity $(\varepsilon)$, mean $\varepsilon$ daily values from May to August were used, covering a dry season and a part of the wet season, from September to December.

After estimations, the $\varepsilon$ values were divided by periods and Mean Absolute Deviation (MAD), Mean Squared Error (MSE), and coefficient of determination $\left(\mathrm{R}^{2}\right)$ were calculated using linear regression without interception. Willmott's index of agreement (d), the Pearson correlation coefficient ( $r$ ), and the confidence coefficient or Camargo and Sentelhas performance (c) were calculated as well, as shown in Table 3.

Low error values for the wet season (September to December) showed that the models adjust to the study area, where the variation ranges of MAD (-0.07 to -0.13$)$, MSE (0.19 to $0.22)$, and $\mathrm{R}^{2}$ ( 0.93 to 0.95$)$ were lower than the values for the dry season. For the dry season, MAD ranged from -0.09 to -0.12 , MSE ranged from 0.18 to 0.27 , and $\mathrm{R}^{2}$ varied from 0.89 to 0.96.

Negative MAD values indicate underestimation, while positive values indicate overestimation. We noted that the six models tend to underestimate atmospheric emissivity values. Due to lack of studies about atmospheric emissivity in literature, the performance of our estimates were compared to Von Randow and Alvalá (2006) and Aguiar et al. (2011). Those studies estimated ORL using the same models. This underestimation tendency was also found by to Von Randow and Alvalá (2006) and Aguiar et al. (2011), which indicated that the problems could be related to the coefficients used on the equations, which are adjusted to other regions.

It is possible to observe in Table 3 that the Pearson correlation coefficient (r) values for dry period are above 0.3 , which are characterized as intermediate and high correlations, 
indicating good precision when compared to monthly average. Idso and Jackson method obtained the lowest value for dry season, while Brutsaert, Bignami, and Idso models showed the best coefficient with a value of 0.59 each one.

For the wet season, the $\mathrm{r}$ values were very low and considered as low and very low. Idso and Jackson equation indicated the best effectiveness, with an $r$ value of 0.31 . The other methods obtained $r$ values lower than 0.30 and were interpreted as low correlation.

About the confidence coefficient or Camargo and Sentelhas performance (c), for wet season, very poor performance were found for every method used. For dry season, the best results were found for Brutsaert, and Idso models, which indicated poor performance, and the other methods were determined as very poor.

Table 3. Statistical analyses of observed (computed by energy balance equation) and estimated atmospheric emissivity values.

\begin{tabular}{|c|c|c|c|c|c|c|c|c|}
\hline \multicolumn{9}{|c|}{ Dry season } \\
\hline Method & MAD & MSE & $\mathbf{R}^{2}$ & d & $\mathbf{r}$ & Classification & c & Performance \\
\hline Idso and Jackson & -0.07 & 0.22 & 0.93 & 0.32 & 0.33 & Intermediate & 0.11 & Very Poor \\
\hline Swinbank & -0.09 & 0.22 & 0.93 & 0.38 & 0.41 & Intermediate & 0.15 & Very Poor \\
\hline Brutsaert & -0.09 & 0.20 & 0.94 & 0.72 & 0.59 & High & 0.42 & Poor \\
\hline Brunt & -0.05 & 0.20 & 0.95 & 0.71 & 0.55 & High & 0.39 & Very Poor \\
\hline Bignami & -0.13 & 0.22 & 0.93 & 0.68 & 0.59 & High & 0.40 & Very Poor \\
\hline Idso & -0.07 & 0.19 & 0.95 & 0.73 & 0.59 & High & 0.43 & Poor \\
\hline \multicolumn{9}{|c|}{ Wet season } \\
\hline Method & MAD & MSE & $\mathbf{R}^{2}$ & d & $\mathbf{r}$ & Classification & c & Performance \\
\hline Idso and Jackson & -0.09 & 0.18 & 0.96 & 0.31 & 0.31 & Intermediate & 0.09 & Very Poor \\
\hline Swinbank & -0.12 & 0.27 & 0.89 & 0.18 & -0.12 & Low & -0.02 & Very Poor \\
\hline Brutsaert & -0.10 & 0.24 & 0.92 & 0.16 & -0.17 & Low & -0.03 & Very Poor \\
\hline Brunt & -0.10 & 0.24 & 0.92 & 0.16 & -0.17 & Low & -0.03 & Very Poor \\
\hline Bignami & -0.10 & 0.20 & 0.94 & 0.26 & -0.07 & Very Low & -0.02 & Very Poor \\
\hline Idso & -0.08 & 0.22 & 0.94 & 0.16 & -0.16 & Low & -0.02 & Very Poor \\
\hline
\end{tabular}

Idso equation obtained the highest $\mathrm{R}^{2}$ value for the dry season, a high $\mathrm{R}^{2}$ value of 0.94 for wet season, evidencing low error values compared to observed data, and the best $r$ and $c$ values for dry season, which represent the errors in comparison with regression equation.

For the wet season, the model with best performance was the Idso and Jackson equation, being the only method used with positive $c$ and the highest $\mathrm{R}^{2}$ value, 0.96 .

The Brutsaert, Brunt, and Bignami equations had similar results. On the other hand, the Swinbank and Idso and Jackson methods results were very much alike too, and both models consider Tar only.

Figures 2 and 3 show values of daily average cycle of atmospheric emissivity, and it is possible to observe again that the values in the wet season are higher than in the dry season, and that the modelled values underestimate the emissivity found by energy balance equation.

For the dry season, Idso and Brutsaert equations showed the best model performances. On the other hand, the equation developed by Idso and Jackson results were more efficient for the wet season, where thermal amplitude is low, showing a sensitivity of this equation to the air temperature variation, since water vapor practically does not vary throughout the day.

Regarding the energy available to the environment, since atmospheric emissivity varied seasonally, with higher values observed during the wet season, the average energy of longwave radiation (ORL) that comes from the available atmosphere also varied from one period to another. Considering the higher emissivity during the wet season, during this period there was a higher availability of energy to the environment (Curado et al., 2011). 


\section{CONCLUSIONS}

The equations evaluated in this study showed poor performance during the studied year, and only during the dry season was their performance acceptable. Those results were expected, since high cloudiness conditions negatively affected the models' performance for the wet season.

For dry season, the methods that consider water vapor pressure and air temperature show better performance than models that consider air temperature only, as with the Swinbank (1963) and Idso and Jackson (1969) equations. However, for the wet season, the Idso and Jackson (1969) model is more efficient, indicating a sensitivity associated to the air temperature.

The Idso (1981) and Brutsaert (1975) equations show better performance for the study area, obtaining higher indexes of agreement. Therefore, these models are the most suitable methods to estimate atmospheric emissivity for campo sujo Cerrado.

\section{ACKNOWLEDGEMENTS}

We acknowledge Programa Pós-Graduação em Física Ambiental (PPGFA) for provides data, and its professors for data collection, without their support, this study could not be developed. This study was financed in part by the Coordenação de Aperfeiçoamento de Pessoal de Nivel Superior - Brasil (CAPES) - Finance Code 001. The authors are also grateful to Dr. Clovis Miranda and his family for allow this study to be developed at the Fazenda Miranda.

\section{REFERENCES}

AGUIAR, L. J. G.; FISCH, G. R.; FERREIRA, W. P. M.; COSTA, A. C. L. D.; COSTA, J. M. N. D.; AGUIAR, R. G. Estimativa da radiação de onda longa atmosférica em áreas de floresta e de pastagem no sudoeste da Amazônia. Revista Brasileira de Meteorologia, v. 26, n. 2, p. 215-224, 2011. https://dx.doi.org/10.1590/S0102-77862011000200006

BIGNAMI, F.; MARULLO, S.; SANTOLERI, R.; SCHIANO, M. E. Longwave radiation budget in the Mediterranean Sea. Journal of Geophysical Research, v. 100, n. C2, p. 2501-2514, 1995. https://doi.org/10.1029/94JC02496

BIUDES, M. S.; VOURLITIS, G. L.; MACHADO, N. G.; ARRUDA, P. H. Z.; NEVES, G. A. R.; ALMEIDA, L. F.; SOUZA, N. J. Patterns of energy exchange for tropical ecosystems across a climate gradient in Mato Grosso, Brazil. Agricultural and Forest Meteorology, v. 202, p. 112-124, 2015. http://dx.doi.org/10.1016/j.agrformet.2014.12.008

BRUNT, D. Notes on radiation in the atmosphere. I. Quarterly Journal of the Royal Meteorological Society, v. 58, n. 247, p. 389-420, 1932. https://doi.org/10.1002/qj.49705824704

BRUTSAERT, W. On a derivable formula for long-wave radiation from clear skies. Water Resources Research, v. 11, n. 5, p. 742-744, 1975. https://doi.org/10.1029/WR011i005p00742

CPRM. Folha SD-21 Cuiabá: atlas hidrogeológico do Brasil ao milionésimo. Projeto RadamBrasil. Brasília, 1982.

CURADO, L. F. A; RODRIGUES, T. R.; BIUDES, M. S.; DE PAULO, S. R.; DE PAULO, I. J. C.; DE SOUZA NOGUEIRA, J. Estimativa sazonal da emissividade atmosférica através da Equação de Brutsaert no norte do Pantanal Mato-grossense. Ciência e Natura, v. 33, n. 2, p. 167-180, 2011. http://dx.doi.org/10.5902/2179460X9368 
DUARTE, F.; DIAS, L.; MAGGIOTTO, S. R. Assessing daytime downward longwave radiation estimates. Agricultural and Forest Meteorology, v. 139, p. 171-181, 2006. https://doi.org/10.1016/j.agrformet.2006.06.008

FARIA, T. O.; RODRIGUES, T. R.; CURADO, L. F. A.; GAIO, D. C.; NOGUEIRA, J. S. Surface albedo in different land-use and cover types in Amazon forest region. Revista Ambiente e Água, v. 13, p. 1-13, 2018. http://dx.doi.org/10.4136/ambi-agua.2120

FOOD AND AGRICULTURE ORGANIZATION OF THE UNITED NATIONS. Report on the expert consultation on procedures for revision of FAO guidelines for prediction of crop water requirements. Roma, 1991. p. 45.

GIAMBELLUCA, T. W.; SCHOLZ, F. G.; BUCCI, S. J.; MEINZER, F. C.; GOLDSTEIN, G.; HOFFMANN, W. A.; BUCHERT, M. P. Evapotranspiration and energy balance of Brazilian savannas with contrasting tree density. Agricultural and forest meteorology, v. 149, n. 8, p. 1365-1376, 2009. https://doi.org/10.1016/j.agrformet.2009.03.006

HEITOR, A.; BIGA, A. J.; ROSA, R. Thermal radiation components of the energy balance at the ground. Agricultural and Forest Meteorology, v. 54, n. 1, p. 29-48, 1991. https://doi.org/10.1016/0168-1923(91)90039-S

IDSO, S. B.; JACKSON, R. D. Thermal radiation from the atmosphere. Journal Geophysical Research, v. 74, n. 23, p. 5397-5403, 1969. https://doi.org/10.1029/JC074i023p05397

IDSO, S. B. A set of equations for full spectrum and 8 to 14 ìm and 10.5 to $12.5 \mu \mathrm{m}$ thermal radiation from cloudless skies. Water Resources Research, v. 17, n. 2, p. 295 304, 1981. https://doi.org/10.1029/WR017i002p00295

JIMÉNEZ, J. I.; ALADOS-ARBOLEDAS, L.; CASTRO-DÍEZ, Y. et al. On the estimation of long-wave radiation flux from clear skies. Theoretical and applied climatology, v. 38, n. 1, p. 37-42, 1987. https://doi.org/10.1007/BF00866251

KLINK, C. A.; MOREIRA, A. G. Past and current human occupation, and land use. In: OLIVEIRA, P. S.; MARQUIS, R. J. (Eds.). The cerrados of Brazil: ecology and natural history of a neotropical savanna. New York: Columbia University Press, 2002. p. 69-88.

MACHADO, N. G. et al. Estimation of rainfall by Neural Network Over A Neotropical Region. $\begin{array}{llllll}\text { Revista Brasileira de } & \text { Climatologia, }\end{array}$ https://dx.doi.org/10.5380/abclima.v17i0.40799

NOGUEIRA, J. S.; LIMA, E. A. Coletânea física ambiental I. São Paulo: Baraúna, 2011.

NOVAIS, J. W. Z.; SANCHES, L.; MACHADO, N. G.; SILVA, L. B.; AQUINO, A. M.; RODRIGUES, T. R. Variação horária e sazonal da radiação solar incidida e refletida e suas relações com variáveis micrometeorológicas no Pantanal Norte Mato-grossense. Revista Brasileira de Ciências Ambientais, v. 38, p. 96-108, 2015. http://dx.doi.org/10.5327/Z2176-947820150053

PRATA, A. J. A new long wave formula for estimating downward clear sky radiation at the surface. Quartely Journal of the Royal Meteorological Society, v. 122, p. 1127 1151,1996. https://doi.org/10.1002/qj.49712253306

RODRIGUES, T. R.; VOURLITIS, G. L.; LOBO, F. A.; OLIVEIRA, R. G.; NOGUEIRA, J. D. S. Seasonal variation in energy balance and canopy conductance for a tropical savanna ecosystem of south central Mato Grosso, Brazil. Journal of Geophysical Research: Biogeosciences, v. 119, n. 1, p. 1-13, 2014. http://dx.doi.org/10.1002/2013JG002472 
RODRIGUES, T. R.; CURADO, L. F. A.; PEREIRA, V. M. R.; SANCHES, L.; NOGUEIRA, J. S. Hourly interaction between wind speed and energy fluxes in Brazilian Wetlands Mato Grosso - Brazil. Anais da Academia Brasileira de Ciências, v. 88, n. 4, p. 2195 2209, 2016. http://dx.doi.org/10.1590/0001-3765201620150130

SAN JOSÉ, J. J.; NIKONOVA, N.; BRACHO, R. Comparison of factors affecting water transfer in a cultivated paleotropical grass (Brachiaria decumbens Stapf) field and a neotropical savanna during the dry season of the Orinoco lowlands. Journal of Applied Meteorology, v. 37, n. 5, p. 509-522, 1998. https://doi.org/10.1175/15200450(1998)037\%3C0509:COFAWT\%3E2.0.CO;2

SCHOLES, R. J.; ARCHER, S. R. Tree-grass interactions in savannas. Annual review of Ecology and Systematics, v. 28, n. 1, p. 517-544, 1997. https://doi.org/10.1146/annurev.ecolsys.28.1.517

SWINBANK, W. C. Long-Wave Radiation from clear skies. Quarterly Journal of the Royal Meteorological Society, v. 89, n. 381, p. 339-348, 1963. https://doi.org/10.1002/qj.49708938105

TETENS, V. O. Über einige meteorologische Begriffe. Gesellschaft: Friedrich Vieweg \& Sohn Akt, 1930. p. 297-309.

VON RANDOW, R. C. S.; ALVALÁ, R. C. S. Estimativa da radiação de onda longa atmosférica no pantanal sul mato-grossense durante os períodos secos de 1999 e 2000. Revista Brasileira de Meteorologia, v. 21, n. 3b, p. 398-412, 2006.

VOURLITIS, G. L.; DA ROCHA, H. R. Flux dynamics in the cerrado and cerrado-forest transition of Brazil. In: HILL, M. J.; HANAN, N. P. (Eds.). Ecosystem function in global savannas: measurement and modeling at landscape to global scales. Boca Raton: CRC Press, 2011. p. 97-116.

WILLMOTT, C. J.; ACKLESON, S. G.; DAVIS, J. J.; FEDDEMA, K. M.; KLINK, D. R. Statistics for the evaluation and comparison of models. JGR Oceans, v. 90, p. 89959005, 1985. https://doi.org/10.1029/JC090iC05p08995 